\title{
Regulation Distance, Labour Segmentation and Gender Gaps
}

\begin{abstract}
Existing theories on human capital, labour market segmentation and discrimination fail to fully explain gender gaps-for example, the large gender gap in elite occupations where women apparently possess high labour market power. This article seeks to extend our understanding, through the interaction between labour segmentation, regulation content and regulation distance, the last referring to the extent to which employment of particular workers is (un)regulated, including by collective agreements, legislation or other instruments. Regulation distance encompasses a continuum from 'regulation proximity' to 'market proximity'. A greater reliance on the 'market' does not necessarily remove pay distortions; rather, it might increase their impact through the mechanism of gendered norms. Empirical evidence is drawn from studies in several countries, most commonly Australia. This approach more clearly specifies the roles of under-valuation, labour segmentation, group norms and human and social capital; illuminates public sector and union effects; explains why the gender gap is greatest for a group of women with the most labour market power; and illustrates some non-pay aspects of gendered experience at work.
\end{abstract}

Forthcoming as: Peetz, D, 'Regulation distance, labour segmentation \& gender gaps', Cambridge Journal of Economics. November 2014, doi: 10.1093/cje/beu054. (Use the published version, not this, as the authoritative version, as that has final corrections and the linke.) 


\section{Regulation Distance, Labour Segmentation and Gender Gaps}

The purpose of this paper is to reconsider some aspects of our thinking on the 'gender gap'. The term is typically used to refer to proportionate difference in the wages received by men and women (the 'gender pay gap') but here it is conceived more broadly as relating to differences both in pay and in other workplace outcomes including the conditions under which work is performed.

Conventional economic theory defines distortions in the setting of pay as minimised when markets are able to most freely operate (Ehrenberg and Smith 1997). Under that logic, the earnings of male and female employees should reflect the skills they possess and the demand for those skills, regardless of gender. Yet casual observation tells us that women are paid less per hour than men. After 'human capital' variables such as education and experience, associated with conventional theory, are accounted for, 'unexplained' differences persist (Tharenou 2013). Several models of discrimination have arisen in order to try to explain this. Outside of conventional economics, an important development has been the emergence of labour market segmentation theory, which questions the notion of freely operating markets in which employers are, in effect, price takers rather than price makers (Brosnan 1996, Rubery 2005, Beynon et al. 2002, Reid and Rubin 2003). Yet even with this, important issues remain unanswered.

Highlighting this explanatory gap is the situation of women in higher status occupations. Such occupations wield substantial class power. It is widely acknowledged they employees in high-paid jobs have greater labour market power than those in segmented, lower skilled jobs. They have higher work-related skills, are the most highly 
educated and therefore most aware of their rights when it comes to fighting issues of discrimination and harassment. So if there were one group of women whom we would expect to achieve equality in pay and conditions, it would be those in the highly paid, high status jobs. Yet, as we shall see below, gender inequality in pay appears, if anything, to increase as women approach the top.

In order to explain this, we have to move beyond conventional human capital theory and integrate labour market segmentation theory with another concept introduced here, that of 'regulation distance'. This term means the extent to which the terms of employment of particular workers are (un)regulated, including by collective agreements, legislation or other instruments. It refers to a continuum from 'regulation proximity' to 'market proximity'. When regulation distance is low, we say that workers have high 'regulation proximity': a set of objective criteria - rules - determine most aspects of their employment (it is not possible for rules to determine all aspects of the open-ended employment relationship), and there is limited room for subjective factors, such as whether workers are from the same social milieu as their bosses or look or behave similarly to them, to influence pay and conditions. In the UK, for example, it is shaped by the extent to which employment is regulated by collective agreements or legislation; in Australia, tribunal awards are added to this list. This concept is relevant not only for understanding the situation of high status women but of working women in many situations.

When regulation distance is high, we could say workers have 'market proximity' or, in many cases, 'subjective proximity'. Hence 'market proximity' does not mean that pay 
and conditions are governed by simple laws of supply and demand, and the human capital model. High regulation distance reduces the inherent role of objective criteria and increases the potential role of subjective criteria. It increases the likelihood that norms and cultures that favour those in power (men) will dominate outcomes. Whereas Becker (1957), in describing how employers may in effect pay a premium (higher wages or lost productivity) to satisfy their preference or 'taste' for certain types of labour (eg male or white labour), put forward a model that in effect indicated that discrimination would be self-defeating in a market context (discriminating employers would eventually go broke), a 'regulation distance' model suggests that greater reliance on the 'market' need not remove distortions and may increase their impact.

The extent to which subjective criteria rule is influenced by how 'visible' women workers are in that particular market - that is, whether those on the 'demand' side of the labour market can tell the gender of those on the 'supply' side. Gender can only influence outcomes where it is known. Where gender is known and influential, we call this a 'subjectified' market; where it is unknown, we call this an 'objectified' market. The degree of subjectification will be one factor influencing market 'norms'. In principle, a market in which labour was supplied anonymously through an opaque intermediary (such as the internet) would be objectified and unable to generate discriminatory outcomes. Some 'contract for' service arrangements may be like this (eg contract writing of software or articles. interpretation of radiographic images, etc (Yu and Levy 2010), but few if any employment relationships are like this at present. Still, in some regulation-distant labour markets, delivery of a simply defined output with simply defined value may be the principal concern of management, and the labour 
market might be more objectified than in some other regulation-distant markets for labour for which personal interactions are the dominant mode of generating value (for example, for management positions).

So regulation distance is not the only factor influencing gender gaps. In addition to the nature of market norms, the content of regulation matters critically, and regulation distance operates differently for different labour market segments. So we have to consider how regulation distance and labour segments interact: in particular, whether work women are undertaking is female-dominated, male-dominated or mixed.

These ideas are elaborated upon below. First, we consider the factors that are commonly used to explain the gender pay gap. We then discuss empirical evidence and theoretical propositions on the roles in shaping gender gaps played by: the content of regulation and norms; regulation distance; labour market segmentation; and the intersections between these latter two. Evidence is drawn from a number of countries, most commonly Australia. We conclude with some implications for theory and policy. While the gender gap should be conceived as encompassing matters beyond wages, the data mostly relate to wages.

\section{Explaining gender gaps}

Human capital theory seeks to explain gender gaps in terms of human capital 'endowments' - different income-earning characteristics, particularly education, and 
experience. Workers experience costs by undergoing education or training, and then receive a return on their investment as higher earnings (Norris, Kelly and Giles 2005). Women may have lower earnings than men because they possess fewer endowments; or they may receive a lower return on those endowments. However, studies indicate that differences in the human capital characteristics of men and women explain little of the gender pay gap (Healy, Kidd and Richardson 2007, Cassells et al. 2009b). There is more substantial evidence that women receive lower returns from education and experience than do men, especially in the upper ends of the private sector earnings distribution (Cassells et al. 2009b). But this implies the question: why are returns lower for women?

Other studies have suggested various labour market factors play a role in gender gaps. Women tend to be segregated into particular industries and occupations, and those with high rates of female employment tend to have lower average rates of pay (Cassells et al. 2009b). The gender pay gap tends to be lower amongst union members than nonmembers, particularly for lower wage earners (Card, Lemieux and Riddell 2003, Blanchflower and Bryson 2004). It tends to be lower amongst people in the lower half of the earnings distribution and higher in the top part, especially within the private sector (Cassells et al. 2009b, Kee 2006). When education is correlated with income, a higher gender gap for high income earners mathematically reduces the apparent returns for education for women.

Labour market segmentation theory explains some aspects of gender pay gap. The demand side of labour markets (in particular, the practices of employers) and the 
supply sides (divided by class, gender, race, skill or qualification) interact to create social differentiations that create unequal access to employment and income, thereby segmenting labour markets (Rubery 2005). By separating workers into groups with different bargaining power and status, workers with similar productivity are paid differently (Brosnan 1996). On the demand side, gender segmentation can arise from a number of sources including employer flexibility strategies aimed at recruiting large, 'casual' workforces, other employer strategies to build and reproduce internal labour markets with committed, secure and reliable (male) employees, employer discrimination and career blocks in part-time work. On the supply side, factors include the social definition of 'women's jobs' related to the domestic sphere, their portrayal as possessing less skill than men's jobs, and male resistance to women in 'men's jobs' (Power 1975, Rubery 2005). Segmentation divides 'male' and 'female' jobs; it also segments employees from migrant backgrounds, intermittently unemployed people, indigenous people and people with disabilities. Within firms, pay hierarchies may reflect gender rather than 'the internal value of jobs' in an organisation (Rubery 2005). In segmented labour markets, skills (eg 'caring' or 'dexterity) associated with women are given less value than those (eg 'strength') associated with a more powerful grouping, men (Brosnan 1996).

Despite its usefulness in explaining low pay in female-dominated occupations, labour market segmentation theory does not adequately explain other aspects of the gender pay gap. For one thing, many women are not 'segmented' into female-dominated occupations or industries. In 2009, when women constituted 46 per cent of the employed Australian workforce, amongst the 99 ABS industry subdivisions, a third of 
women worked in industries where they constituted a minority of industry employment, and half worked in industries where they constituted less than 56 per cent of employment (ABS Cat No 6291.0.55.003). Nor does labour market segmentation theory explain the phenomenon of a widening pay gap at high pay levels.

At the cross-national level, differences in the egalitarian characteristics of wage structures play an important part in explaining gender gaps, as women in all countries are overrepresented in lower-status occupation and under-represented in higher status jobs (Blau \& Kahn 2001). Class is thus an important factor in national gender gaps, as is (in complex ways) the nature of welfare state programs (Mandel and Shalev 2009). Our interest, though, is also in explaining gender gaps within countries, as they apply to different women in different labour market positions.

\section{The content of regulation and norms}

Regulation reflects (and reinforces) dominant social norms which in turn reflect, not without challenge, the interests of the dominant group(s) - in this case, men. Regulation distance only matters when there is some difference between the values embodied in regulation (manifested as rules) and the values embodied in the market (manifested as the culture and norms that operate under market/subjective proximity). In the early nineteenth century, there was little if any difference between the two for most workers, and the concept of regulation distance would have had little salience. The Australian arbitration tribunal's 1907 'Harvester' judgement and related rulings on female pay reflected and reinforced the dominant social norms and interests of men 
(Macarthy 1975, Beyrer 1975). Through a century of women's struggle, social attitudes and legislation changed to greater value women's work. Countless examples of class and feminist struggle led, directly or indirectly, to the introduction of regulation that in one way or another advanced the interests of women. They forced employers, management and some workers to do things that they otherwise would not have done. Equal pay legislation in the UK and other countries (Whitehouse, Zetlin and Earnshaw 2001), and the introduction in Australia through the tribunal system of equal pay for equal work (and later equal pay for work of equal value), imposed new behaviours on employers. The content of legislation as it affects women at work (including direct regulation of wages, leave, parental leave and discrimination, as well as welfare state policies such as those affecting child care, child allowances and state payments), varies substantially between nations (Whitehouse 1992; Mandel and Shalev 2009), and this helps us understand cross-national differences in gender outcomes. Between them, regulation and norms shape what Connell (2006) calls the 'gender relations of power' how control, authority and force, including hierarchy and legal power, are organised along gender lines - one of her four dimensions of gender regimes. Some of these regulations - for example, uniform minimum wage laws - may have the appearance of being gender neutral even though they have important implications for gender.

An important aspect of regulation content arises through union values, embodied in the regulation unions enact. For example, in Australia for many decades trade unions gave little attention to women (eg Storer and Hargreaves 1976), and actively supported unequal wages for men and women. This reflected the dominance of the 'family needs' 
or 'male breadwinner' notion in wage fixing and union ideology. Discrimination against women was as much a result of union pressure as it was of employer decisions. However, from the 1960s—under the rising influence of the women's movementunion policy changed and unions supported a range of equal pay campaigns and the promotion of women and women's policies within unions. While women remain underrepresented in unions at all levels, most severely at senior levels of unions, underrepresentation is declining (Pocock 1995, 1992, Bramble 1995, Nightingale 1991, Parker and Douglas 2010, Cooper 2012).

Similarly important is the content of norms. The norms that are relevant in this respect are driven by the values of people in positions of power in a given situation, not the values of the population at large. In two workplaces or occupations with market proximity, the norms for a female-dominated one will be very different to those for a male dominated one. The idea of 'norms' relates to two of Connell's four dimensions of gender regimes: emotion and human relations (how antagonisms or attachments are organised along gender lines) and culture and symbolism (the language, symbols, definitions, beliefs and attitudes about gender) (Connell 2002, 2006). Norms will likely vary with education, as education tends to diminish intolerance and be linked to more positive attitudes towards women's employment (Bates and Heaven 2001, Shu 2004, Crompton and Lyonette 2005, Dunn et al. 2004). Education effects may mask the impact of regulation distance, as protective labour market laws tend to be extended to those with greatest vulnerability, who typically have the lowest skills and education. Norms may also vary with employer values and (conscious or unconscious) strategy, nationality, location, cultural setting and other factors. As a result, subjective proximity 
in a occupation where norms favour equality will have a very different impact to that in an occupation where norms favour men or downplay objective criteria for pay determination.

\section{Features of and evidence on regulation distance}

Several dimensions of employment for an occupation or group of female workers will vary according to where they are on the regulation distance continuum. The following discussion describes differences between groups at the polar ends of regulation proximity and market/subjective proximity. While many groups of workers will sit at one pole or the other, many others will occupy intermediate steps in the continuum, and their characteristics will likewise have appropriately intermediate characteristics.

1. For workers with regulation proximity, the governance system of employment, including wages, is based on rules. For workers in subjective proximity, by contrast, employment is governed not by rules but by the norms of the groups who possess power. The public sector has high regulation proximity, using a web of rules to govern employment more consistently than the private sector. So it is that the gender wage gap is smaller in the public than the private sector (Preston 2000, Kee 2006, Barón and Cobb-Clarke 2008, Cassells et al. 2009a, Pfeffer and Ross 1990). Likewise the gender wage gap widened in the private sector, but remained stable in the public sector, during years when laws undermined collective bargaining power in Australia (Peetz 2007). 
2. Related to this, the rule of law is significant for workers with regulation proximity. Where rules exempt from regulation workers with incomes above a certain level or in certain type of occupations or with certain modes of employment (such as 'independent' contractors or outworkers) then market proximity is high. Outworkers are documented as having minimal protections (eg Thorpe in Centre for Research on Employment and Work and Socio Legal Research Centre 2000). If state authorities do not substantially enforce minimum employment standards, or if the processes, rules or costs of the legal system discourage enforcement, then market proximity is increased for all workers so affected, and they become more reliant on unions. 'Hard law' brings about regulation proximity, 'soft law' - the feature of recent European Union legislation in the area of gender gaps (Smith 2012) - increases regulation distance.

Enforceability is not just about state agency actions. It is also about the access of workers to resources to enforce their rights, and indeed their awareness of those rights. State inspectors may enforce minimum wages and conditions, but they often act on complaints that depend on employee willingness to complain and awareness that their rights are being breached. If low-wage workers are most likely to be affected by minimum wage laws, it is high wage earners who are most likely to be aware of antidiscrimination law, and most likely to have the resources to access such law if it is reliant on individuals lodging claims in a court or tribunal against an employer.

3. The employment instrument of workers with regulation proximity will often be a collective agreement that sets out the pay and several conditions of employment of covered employees. By contrast, workers with market proximity will typically be 
covered by a form of individual contract. These contracts will largely be determined by the employer, who has the opportunity to shape norms in the workplace.

In most countries, collective agreements are negotiated by unions. There is scope for pay and conditions to be influenced by local norms, though unions may exercise centralised control over some aspects of locally determined agreements. In much of Europe, the extension of collective agreement coverage across an industry, or at least beyond the workplaces where unions actively negotiated or threatened or took action in support of negotiations for that collective agreement, is a mechanism for enhancing regulation proximity. In Australia, the gender pay gap for workers on collective agreements is typically less than it is for those on individual contracts (Peetz and Preston 2009). In Germany, the gender pay gap is least in firms with collective contracts and wage councils (Gartner and Stephan 2004). Cross-nationally, higher collective bargaining coverage is associated with lower gender pay gaps (Blau and Kahn 2001).

In Australia, a comparable but distinct role to collective agreements is played by awards (regulatory instruments, created by an independent tribunal, which set minimum wages and certain conditions for each occupation covered by that award). Those employees whose wages are determined solely by the award rate are subject to a high level of regulation proximity - to the extent, at least, that the award is enforceable. In recent years the resources put into award enforcement by inspectorates has increased (Goodwin and Maconachie 2010), and the lowest gender pay gap in Australia is for award-reliant workers (Australian Bureau of Statistics 6306.0). 
4. Where collective agreements or public sector pay scales codify and regularise pay, management may increase market proximity by introducing flexibility into pay through incentive or 'performance' related pay. This frequently has the effect of increasing the use of subjective criteria at the expense of objective criteria, which in turn has potentially negative implications for women (Hall 1995, Rubery 1995). For example, a study by the UK Institute of Manpower Studies on merit pay, found that the perceived fairness of PBP criteria varied by gender, such that PBP increased the gender earnings gap (discussed by Hall 1995). The low transparency of performance-related pay has been linked to gender pay inequities (Rubery 1995). Transparency, then, is typically high where workers have regulation proximity (eg the public sector) and low where they have market proximity (eg individual contracts).

5. The role of unions is often significant for workers with high regulation proximity. Unions are a key form of non-state regulation, seeking to create rules, codify behaviour, and ensure rules are enforced. Most workers with market proximity are non-unionised. In several countries, the union wage premium is greater for women than for men, which suggests that the gender pay gap is smaller amongst union than non-union workers (Card et al. 2003, Blanchflower and Bryson 2004), as unions tend to most benefit those groups who, in the absence of unions, would be in the weakest position in the labour market (Blanchflower 1999, Butcher and Rose 2001, Freeman and Medoff 1984, Jackson and Schellenberg 1999) - though the union wage effect has been declining as union density falls (Blanchflower and Bryson 2004). One factor is that, according to some studies, men and women negotiate differently in individual contracting, with men socialised to be more competitive, acquisitive and confident (Babcock and Laschever 
2003, Barron 2003; Niederle and Vesterlund 2005). Collective union negotiations tend to avoid these problems with individual negotiations.

6. The type of personal capital that is important for shaping pay varies according to regulation distance. For workers with regulation proximity, human capital is important. Greater education and training leads to higher human capital and this in turn leads to increased opportunities for advancement and hence for higher pay, though in internal labour markets this effect may be moderated by tenure.

Human capital also matters for workers with market proximity. However, for this group, social capital also plays a significant role (eg, Ang, Nagel and Yang 2008). Social capital refers to the access to information and connections that people have, and the concept highlights the importance of social networks. These networks act to reproduce and reinforce values. If those values favour the importance of certain types of skills or characteristic over others - for example, privileging physical skills or work over caring skills or work - then those with other skills (women) will be disadvantaged. Through what might be referred to as the 'old boys club', high network connectedness of men to those in power (other men) will give greater access to career opportunities, and pay, to men than women (Tharenou, 1999).

\section{Correlates}

Some other work characteristics will have correlates in regulation distance, though these need not be linear or uniform. Most obvious is income. High income earners are most exposed to market proximity. They are least likely to be subject to minimum wage 
laws, often exempted from certain labour laws (for example, on unfair dismissal), less likely to be unionised (especially when in managerial positions), and more likely to be governed by individual contracts. On the other hand, they have access to the most resources to enforce their rights, and this ability to access the rule of law can be helpful to some women in high positions. They also work in a milieu with, on average, higher education. Empirically, these last two factors are not typically enough to offset the other effects of market proximity. Thus in Australia, for example, there is a higher gender wage gap in the higher earnings brackets of most industry groups and on average, “the gender wage difference at the 10th percentile of men's and women's earnings is only 7.9 per cent. At the 90 th percentile point on the earnings distribution there is a 21 per cent difference between men's and women's earnings" (Austen et al. 2007). Other researchers have also observed that the gender wage gap is higher when managerial employees are included than when they are excluded (Wooden 1999) and that it increases at the top end of the income distribution (Barón and Cobb-Clarke 2008; Kee 2006; Miller 2005). Notably, though, this occurs only in the private sector, not the public sector (Barón and Cobb-Clarke 2008; Kee 2006), where regulation proximity continues much higher up the classification scale. Amongst information and communications technology professionals and scientists, unadjusted annual pay gaps widen and perceptions of pay inequity peak when seniority is high (APESMA 2007). Interestingly, a study of wage inequality in the US showed that union wage effects amongst high income earners were considerably higher amongst women than men (Card 2001), implying union regulation reduces the gender earnings gap at high income levels. The proximity of middle and low income earners to regulation will vary between countries, industries and firms, according to the laws in place, their enforcement, 
exposure and accessibility, and the extent to which they are being paid above the minimum by their employer.

Centralisation of wage fixation implies more extensive regulation proximity. Hence, at the cross-national level, gender equity is higher on average in countries with more centralised forms of wage fixation (Whitehouse 1990,1992) and in countries with higher union density (calculated from data in United Nations 2005, International Labour Organisation 2006).

The frequency of harassment may vary with regulation distance, not only with respect to discrimination law. For example, calls to the Victorian Workplace Rights Information Line regarding discrimination and harassment issues, made by or on behalf of women experiencing problems increased after the introduction of the 'Work Choices' legislation (Gahan 2006), which promoted individual contracting and severely weakened unions. This is because individual work rights, for example, against discrimination and harassment, have little impact if they are not supported by collective rights that, for low income earners, make up for difficulties of awareness, resources and accessibility. Workers appeared likely to lack the confidence, knowledge or resources to assert their rights at work if they did not feel they have the power to protect themselves and ensure that the matter is properly dealt with (Elton et al 2007; Workplace Rights Advocate 2007).

\section{Features of labour market segmentation}


Several additional dimensions of work are a function of the nature of labour market segmentation in an occupation, that is whether it is male-dominated, female-dominated or mixed. These forms of segmentation reflect the fourth dimension of Connell's (2002) gender regimes - that is, the gender division of labour. In male-dominated and femaledominated occupations a gender division of labour in the workplace is very clear. In mixed occupations the gender division of labour within the workplace (or at least, within that occupation within the workplace) may be less clear (though there might be hierarchical gender divisions, that is, women may occupy lower rungs and men higher rungs within the occupation); in all cases, though, the divisions between paid and domestic work - part of Connell's gender division of labour - still matters. The distinctions between the three occupational categories are, empirically, matters of degree: as we saw, there is a diverse distribution of gender shares by occupation (ABS Cat No 6306.0).

1. The impact of the domestic sphere on the value of work varies according to segmentation. In a female-dominated occupation, the skills deployed are typically undervalued, often treated as 'attributes' rather than skills because they often share activities that had been historically undertaken by women in households (Horrell, Rubery and Burchell 1989). This is evident in occupations such as child care, elderly care and nursing, identified as experiencing undervaluation (CREW/SLRC 2000). The higher the female share of employment in an industry (or occupation: Brynin and Güveli 2012:582), the lower are earnings after controlling for education, experience and gender - partly because regulation distance in the form of non-unionism tends to be greater in female-dominated industries (Allen and Saunders 2002). 
By contrast, in a male-dominated occupation the skills or capabilities of individual women may be undervalued, through men's questioning women's ability to ‘do a man's job'. She would, they may argue, be better to 'stay at home' and do domestic work. Men are more likely to reward other men, for example through promotion, especially in male-dominated areas (Kanter 1977).

Hence, the problems of undervaluation are collective in a female-dominated occupation while being individualised in a male-dominated occupation. Hence in a femaledominated occupation, remedies to undervaluation are inherently collective (for example, through prosecuting work value or comparable worth cases in tribunals).

2. There are notable differences between career barriers according to gender segmentation. In female-dominated occupations, career barriers are mainly structural: many female-dominated occupations have much more poorly defined career paths than male-dominated occupations, or paths may be truncated by few opportunities at higher levels. This was clearly evident in a comparison of career paths in male- and femaledominated public sector professional career paths in Queensland, including librarians (Robin Price in CREW/SLRC 2000). In male-dominated occupations, career paths may be clearly defined but career barriers for women arise mainly from restrictions being placed on women accessing promotions or training necessary for career advancement, as a result of direct or indirect discrimination. Just as some women may be told that a particular occupation is not for them, others in that same occupation may be discouraged from, or encounter barriers to, accessing training and career development because gatekeepers to training (supervisors or training providers) believe it to be a 
poor investment, expecting women to perform worse or leave to have children (Murray \& Peetz 2010).

In mixed occupations, the barriers to career advancement may chiefly operate at the procedural interface between the work and domestic spheres. Thus women`s advancement may be hampered by inadequate access to paid maternity leave, permanent part-time work, job sharing or other employee-focused flexibilities that enable women both to have children and exit and re-enter the work force without suffering loss of status or seniority. These procedural interface problems, of course, affect women in all occupations, but in male- and female-dominated occupations they are exceeded by other barriers mentioned in the previous paragraph.

3. Labour segmentation has implications for performance visibility. In mixed occupations, male and female workers are equally visible. But in male-dominated occupations, women are highly visible and their performance is therefore under easy scrutiny. Thus apparent mistakes made by women in the performance of their duties are easily remembered and attributed both to the individual ('she's not up to it') and the gender ( I said women can't do this job') and achieve exaggerated status, whereas those by men are easily forgotten or passed off as within normal bounds (Kanter 1977). Women therefore report having to work harder than men in order to achieve recognition or promotion (Murray and Peetz 2010).

Conversely men in female-dominated occupations are also highly visible, but whether judgement of their performance is similarly skewed depends on whether they 'cross 
over to do women's work [so that] their status as men is questioned and they become suspect (Susan Murray 2001); hence 'moral panic' over their role (Piper \& Smith 2003) has led to men's departure from primary education (Stewart 2001) and they are similarly rare in child care. Yet male nurses or librarians may be unusual rather than 'unsuitable', perhaps even with useful skills (eg strength amongst male nurses).

4. Both men and women may experience harassment at work, but women are far more likely than men to experience sexual harassment (Australian Human Rights Commission 2012), so forms of harassment experiences will also vary by labour segmentation. In female-dominated and mixed work spaces, sexual harassment events are likely to be individualised: an individual co-worker, supervisor or manager harasses a female employee or contractor. In male-dominated work spaces, harassment can be of this form but it may also take on a collective form. A frequent example is female pornography posted on walls or in magazines in common rest areas (Eveline and Booth 2002). Such environments increase the potential for, and perceived legitimacy of, individual acts of harassment. Just as individual sexual harassment, particularly from supervisors, is an expression of male power over individual females, so too collective harassment behaviour can be a way of reinforcing male power in the workplace. Often collective behaviours may not meet what the law would consider to be criteria for 'harassment', and may consist of frequent 'blue' jokes or swearing (Eveline and Booth 2002).

\section{Interactions and gender gaps}


We can visualise the interaction of regulation distance and labour segmentation in modern times (where regulation norms are more female-friendly than the norms of those in positions of power) along the lines of Figure 1. The chart shows the location of several groups of women workers in an Australian context. For ease of reference, labels have been attached to male-dominated (M), female-dominated (F) and mixed (X) occupations, and to workers with regulation proximity (1) and subjective/market proximity (2). Thus the chart shows six segments, for example, M1 is a male-dominated segment with regulation proximity.

Some of the groups shown in Figure 1 may be located differently in different countries. For example, mining is a male-dominated industry in most countries, but in Australia coal is relatively well unionised whereas metals mining is non-union and dominated by individual contracts. So coal (at M1) has greater regulation proximity than metals mining (M2). 


\begin{tabular}{|c|c|c|c|}
\hline & \multicolumn{2}{|c|}{ Regulation distance } \\
\hline & & $\begin{array}{l}\text { regulation } \\
\text { proximity }\end{array}$ & $\begin{array}{c}\text { market } \\
\text { proximity }\end{array}$ \\
\hline 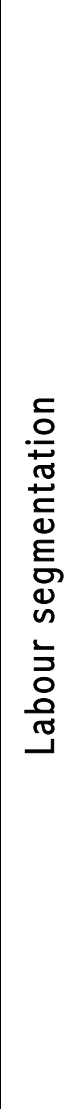 & $\begin{array}{l}\text { Male- } \\
\text { dominated }\end{array}$ & $\begin{array}{c}\text { (M1) } \\
\text { coal mining } \\
\text { (X1) } \\
\text { academics } \\
\text { public servants } \\
\\
\text { (F1) } \\
\text { child care } \\
\text { aged care } \\
\text { nurses } \\
\text { librarians }\end{array}$ & $\begin{array}{c}\text { (M2) } \\
\text { senior executives } \\
\text { engineers } \\
\text { high finance } \\
\text { metals mining(?) } \\
\text { (X2) } \\
\text { retail managers } \\
\text { solicitors } \\
\text { accountants } \\
\text { (F2) } \\
\text { clothing outworkers } \\
\text { private household staff }\end{array}$ \\
\hline
\end{tabular}

Figure 1: Examples of locations of women workers by regulation distance and labour segmentation, Australia

The intersections between regulation distance and labour segmentation help shape the nature and size of gender gaps and the disadvantages facing women. It is worth at this point again distinguishing between 'internal' and 'external' gender pay gaps: an internal gender pay gap exists when people in the same occupation doing the same work are 
paid differently as a result of their gender ('unequal pay for equal work'). An external gender pay gap exists when people in different occupations are doing work of equal worth but paid differently as a result of their gender ('unequal pay for work of equal value').

For women in segment M1 (male-dominated, regulation proximate), the internal hourly gender pay gap tends to be low, especially in relation to base pay and conditions (Murray \& Peetz 2010). There may be issues arising from specific interfaces with the domestic sphere (for example there may be lower benefits for part-timers), and impediments to women obtaining training or career advancement on the basis that such investments may not achieve 'returns'. Performance pay may also create gender gaps. The main problems for women are thus in terms of non-wage discrimination as well as harassment, which has the potential to have a collective as well as an individual form.

For women in segment F1 (female-dominated, regulation proximate), the internal gender pay gap also tends to be low but the main problem is a (potentially large) external gender pay gap due to undervaluation, at least until such times as undervaluation can be remedied through changes to regulation. Amongst the femaledominated occupations are several which have featured in reports of skills undervaluation, including child care workers, nurses, aged care workers and librarians (CREW/SLRC 2000). For at least the first three, the research suggests the norms built into the regulation system have codified that undervaluation, principally through the inadequate application of work value principles by industrial tribunals. For many 
women in segment F1, there may also be structural barriers to career advancement - as with, for example, librarians (see Robin Price in CREW/SLRC 2000).

For women in segment X1 (mixed, regulation proximate), the internal pay gap for base pay again tends to be low and the external gender pay gap is not an issue. Harassment tends to be restricted to individualised forms. More significant problems for gender pay equity are likely to be individualised barriers to career progression arising in part from the interaction between the domestic and paid employment spheres; gender-biased barriers may also be implicitly imposed by managers or structures, though these are less likely to arise than in segment M1. Within such occupations there may still be major differences in the representation of women and their access to lower and higher levels. Thus 'compositional' factors (women being in lower paid, less qualified positions within an occupation) and work-family interactions may appear to be significant in explaining gender gaps within X1 occupations. Public (civil) servants and academics experience regulation proximity. Within this (and other) segments, there may still be substantial differences in regulation proximity. For example, while academics are subject to many rules of employment, universities apply their own variations or interpretations to state rules on matters such as equal employment opportunity, and this tempers some of the regulation proximity. By contrast, public servants have probably the highest regulation proximity of any group. In Australia, the reporting requirements for public service departments on equal employment are more onerous than those on universities and the Public Service and Merit Protection Commission exercises oversight over departments. Academics have, by definition, high education levels, and so we might expect norms to be more favourable to women in academia than 
the bureaucracy. But in this instance regulation proximity triumphs: the distribution of employment in Australian universities amongst academic staff is less favourable to women than that in Australian Public Service employment, especially at the senior academic levels (Strachan et al 2011). Performance pay, bonuses or loadings may be a mechanism for creating windows of regulation distance and opportunities for widening of gender gaps.

Women in segment M2 (male-dominated, market proximate) may potentially face high internal gender gaps in both wage and non-wage conditions. These male-dominated occupations, such as CEOs, engineers and financial market traders, have strong market proximity. Many of the M2 occupations are high paid on average (as per the examples in figure 1), so women in M2 may be receiving higher earnings than those in other segments but the gap between them and men in M2 may be greater than the internal gender gap for women in any of the regulation proximate occupations. We mentioned earlier that for workers in market proximity, employment is governed not by rules but by norms. The norms are those of the groups who possess power, and in this segment it is heavily men. Women in this segment may also experience collective harassment but in many such occupations the likelihood of this occurring is reduced by the education level of their milieu and by their own access to individual resources (eg to sue a discriminatory employer), which discourages collective harassment behaviour.

Social capital plays a key role for this group. We saw earlier the way the gender gap widened near the top of the earnings distribution. The greatest internal gender pay gaps exist for the group that best exemplifies M2: CEOs, senior executives and managers 
(Kulich et al. 2011, Watson 2009, Australian Institute of Management NSW and ACT Limited 2009, Equal Opportunity for Women in the Workplace Agency 2008, Arulampalam, Booth and Bryan 2007, Kulich et al. 2011), where income and personal resources are at their highest but regulation distance is at its greatest. Women executives are less integrated into executive 'old boys' networks (Murray 2006) and have been shown to be less likely to advance through executive ranks than men due to their relative lack of social capital (Tharenou 1999). Given its role in executive pay (Ang, Nagle and Yang 2008) this lack of social capital is one of the critical elements in understanding the very large gender gap in senior executive ranks.

The metaphor of the 'glass ceiling' is frequently used to describe barriers to gender equity in senior executive ranks, but it is rarely theorised as to why this particular phenomenon exists. The concept of regulation distance in intersection with segmentation helps explain the glass ceiling. It arises because the combination of market proximity and male domination together ensure the perpetuation of male power and discrimination against women in rewards and opportunities.

Yet not all women that might appear to be in this group face high gender wage gaps. It depends on the extent of subjectification in markets. The production focus in metals mining, for example, probably makes it a less subjectified labour market than that for senior managers where gender is exposed in every interaction. In Australia, the 2010 internal gender gap in hourly earnings was just 14.6 per cent in metals mining, compared to 12.4 per cent in coal mining (ABS Cat No 6306.0, Table 1a). Small sample sizes make it difficult to be definitive here, and part of the industry-level gender gap 
here is due to women's over-representation in office jobs. Still, it is well below the 40 per cent internal gender gap in annual income evident in Australian taxation statistics for CEOs and managing directors, the 35 per cent for engineering professionals, and the 48 per cent gap for financial dealers (Australian Taxation Office 2012), occupations where part-time work is low and unlikely to seriously influence the comparisons. (For the occupations miners, drillers, shot firers, and mining and construction labourers, the internal annual gender gap in taxation statistics is 21 to 23 per cent; for sales assistant, waiters and bar attendants, typically covered by awards or enterprise agreements and so having regulation proximity, the internal gender gap in taxation statistics is 7 to 10 per cent.) Metals mining also experiences spillover effects from coal mining: employers use individual contracts to offer high wages as a means of replacing and circumventing unions, and so the level of regulation distance is really much lower than it is for CEOs.

Women in segment X2 (mixed, market-proximate), in areas such as such as accountants, retail managers and solicitors (respectively 49, 54 and 56 per cent female in Australia (ATO 2012)), may also face internal gender gaps but these will be a site of frequent contestation. When senior people in these fields are of mixed gender, it is more likely than for M2 that merit, skill and reward for performance may be the sole norms affecting pay for such workers, and that these will interact with the forces of demand and supply to determine final pay outcomes. An even distribution of power across the bargaining table may help ensure the primacy of merit. As the gender distribution of those in power shifts, so too will the norms that influence pay. That is, as women occupy more positions in an occupation in $\mathrm{M} 2$, and it slowly moves towards $\mathrm{X} 2$, they are likely to try to shift the norms towards objective criteria in determining pay and 
conditions. But this will be an uneven process with uneven outcomes, and will depend on occupational struggles and the roles of critical actors. (This latter point also applies, to a lesser degree, to the shift from M1 to X1.)

Women in segment F2 (female-dominated, market proximate) may suffer especially badly from external gender gaps arising from undervaluation. Unlike those in F1, they lack the access to regulation to remedy undervaluation while, unlike many of those in M2, they lack the personal resources to individually challenge instances of genderbiased injustice. They lack access to either individual or collective power. They are thus in the most difficult segment for women of all, the low paid ghettos. As mentioned, clothing outworkers have traditionally been very distant from regulation, not even defined as 'employees' because they undertake piece-work on contract. They have often been rightly characterised as the most exploited of all female workers, with little protection against very low wages, poor conditions and long hours (eg Thorpe in CREW/SLRC 2000).

\section{Concluding remarks}

The interaction between regulation distance and content, labour segmentation and norms helps us understand various aspects of the gender gap. This includes identifying more clearly the roles of undervaluation, labour market segmentation, human capital, social capital, and public sector and union effects. It highlights the importance of group 
norms, social capital and power in shaping the pay of men and women and the situations where those things matter most. We can see that a greater reliance on the 'market' does not necessarily remove distortions, rather it can increase their potential impact. This interaction also illuminates some non-pay aspects of gendered experiences at work, such as harassment, and helps theorise the 'glass ceiling'.

We can draw some possible policy implications. Advancing gender equity requires several things: drawing occupations into regulation (including via collective action and the role of the state); breaking down barriers between segments of the labour market; ensuring regulation values women's work, precludes discrimination and harassment and enables equal career access; and minimising the scope for interference by the domestic sphere in career development. The great gains for women have been made, and are made, through collective action, but that action has lasting impact only where it produces regulation that favours women's employment opportunities and rewards, brings workers within the scope of such regulation and can only be said to be truly effective when segmentation in the labour market is broken down. That is no short term task. 


\section{References}

Allen, J. \& K. Saunders. 2002. Gender Gap in Earnings at the Industry Level. European Journal of Women's Studies, vol. 9, no. 2, 163-180.

Ang, J., G. Nagel \& J. Yang. 2008. Is there a Social Circle Premium in CEO Compensation? In FInancial Management Association European Conference. Prague: (SSRN Working Paper).

APESMA. 2007. Women in the Professions Survey Report 2007. Melbourne: Association of Professional Engineers, Scientists and Managers Australia.

Arulampalam, W., A.L. Booth \& M.L. Bryan. 2007. Is there a glass ceiling across Europe? Exploring the gender pay gap across the wage distribution. Industrial and Labor Relations Review, Vol. 60, No. 2 (January 2007). vol. 60, no. 2, 163-186.

Austen, S., T. Jefferson, A. Preston \& R. Seymour. 2007. Gender pay differentials in lowpaid employment (II). In Australian Fair Pay Commission.

Australian Bureau of Statistics. 6306.0. Employee Earnings and Hours, Australia. Canberra: AGPS.

Australian Human Rights Commission. 2012. Working without fear: Results of the 2012 sexual harassment national telephone survey. Canberra: AHRC.

Australian Institute of Management NSW and ACT Limited. 2009. Report on Gender Pay Differentials. Sydney: Research and HR Consulting Division, AIM, .

Australian Taxation Office. 2012. Taxation statistics 2011-12. Table 13: Individual tax: Selected items, by occupation, gender and taxable income, 2011-12 income year. Canberra: ATO.

Babcock, L. \& S. Laschever. 2003. Women Don't Ask: negotiation and the gender divide. Princeton, NJ, Princeton University Press.

Barón, J.D. \& D.A. Cobb-Clarke. 2008. Occupational Segregation and the gender wage gap in private- and public-sector employment: a distributional analysis. In Discussion Paper No. 3562 Bonn: Institute for the Study of Labor (IZA)

Barron, L.A. 2003. Ask and you shall receive? Gender differences in negotiators' beliefs and requests for a higher salary. Human Relations, vol. 56, no. 6, 635-662.

Bates, C. \& P.C.L. Heaven. 2001 Attitudes to Women in Society: The Role of Social Dominance Orientation and Social Values. Journal of Community Applied Social Psychology, vol. 11, 43-49.

Becker, G.S. 1957. The Economics of Discrimination. Chicago, University of Chicago Press.

Beynon, H., D. Grimshaw, J. Rubery \& K. Ward. 2002. Managing Employment Change: The New Realities of Work. New York, Oxford University Press.

Beyrer, J.B. 1975. Family Allowances in Australia. In Social Policy in Australia: Some Perspectives 1901-1975, ed. J. Roe. Sydney, Cassell.

Blanchflower, D.G. 1999. Changes over time in union relative wage effects in Great Britain and the United States. In The History and Practice of Economics: Essays in honor of Bernard Corry and Maurice Preston, eds. S. Daniel, P. Arestis \& J. Grahl. Edward Elgar.

Blanchflower, D.G. \& A. Bryson. 2004. The Union Wage Premium in the US and the UK. In Industrial Relations Research Association 56th Annual Meeting. San Diego.

Blau, F.D. \& L.M. Kahn. 2001. Understanding international differences in the gender pay gap. In Working Paper 8200. Cambridge MA: National Bureau of Economic Research.

Bramble, T. 1995. Deterring Democracy? Australia's New Generation of Trade Union Officials. Journal of Industrial Relations, vol. 37, no. 3, 401-26. 
Brosnan, P. 1996. Labour Markets and Social Deprivation. Labour and Industry, vol. 7, no. 2, 3-34.

Brynin, M. \& A. Güveli. 2012. Understanding the ethnic pay gap in Britain. Work, Employment \& Society, vol. 26, no. 4, 574-587.

Butcher, K.F. \& C.E. Rose. 2001. Wage effects of unions and industrial councils in South Africa. In Working Paper 2520. Washington DC: World Bank.

Card, D. 2001. The effect of unions on wage inequality in the US labor market. Industrial \& Labor Relations Review, vol. 54, no. 2, 296-315.

Card, D., T. Lemieux \& W.C. Riddell. 2003. Unionization and Wage Inequality: A Comparative Study of the U.S., the U.K., and

Canada. In NBER Working Paper No. 9473. Cambridge MA: National Bureau of Economic Research.

Cassells, R., R. Miranti, B. Nepal \& R. Tanton. 2009a. She works hard for the money: Australian women and the gender divide. In AMP-NATSEM Income and Wealth Report 22. Canberra: AMP / University of Canberra.

Cassells, R., Y. Vidyattama, R. Miranti \& J. McNamara. 2009b. The impact of a sustained gender wage gap on the Australian economy. In Report to the Office for Women, Department of Families, Community Services, Housing and Indigenous Affairs. Canberra: NATSEM, University of Canberra.

Centre for Research on Employment and Work and Socio Legal Research Centre. 2000. Pay Equity in Queensland. eds. D. Peetz \& R. Hunter. Brisbane: Report to Department of Employment Training and Industrial Relations, Queensland Government Submission, Pay Equity Inquiry, QIRC.

Connell, R.W. 2002. Gender. Cambridge, UK, Polity Press.

---. 2006. Glass Ceilings or Gendered Institutions? Mapping the Gender Regimes of Public Sector Worksites. Public Administration Review, vol. 66, 837-849.

Cooper, R. 2012. The Gender Gap in Union Leadership in Australia: A Qualitative Study. Journal of Industrial Relations, vol. 54, no. 2, 131-146.

Crompton, R. \& C. Lyonette. 2005. The new gender essentialism - domestic and family 'choices' and their relation to attitudes. British Journal of Sociology, vol. 56, no. 4, 601-620.

Dunn, K.M., J. Forrest, I. Burnley \& A. McDonald. 2004. Constructing Racism in Australia. Australian Journal of Social Issues, vol. 39, no. 4.

Ehrenberg, R.G. \& R.S. Smith. 1997. Modern labor economics: Theory and practice. Reading, MA, Addison-Wesley.

Equal Opportunity for Women in the Workplace Agency. 2008. Gender income distribution of top earners in ASX200 companies: 2006 EOWA census of women in leadership. Sydney: EOWA.

Eveline, J. \& M. Booth. 2002. Gender and Sexuality in Discourses of Managerial Control: The Case of Women Miners. Gender, Work and Organisation, vol. 9, no. 5, 556578.

Freeman, R.B. \& J.L. Medoff. 1984. What Do Unions Do? New York, Basic Books.

Gahan, P. 2006. WorkChoices \& Workplace Rights in Victoria: Evidence from the Workplace Rights Information Line. Melbourne: Report to the Office of the Workplace Rights Advocate.

Gartner, H. \& G. Stephan. 2004. How Collective Contracts and Works Councils Reduce the Gender Wage Gap. In IAB discussion paper, No. 2004,7. Nürnberg Institut für Arbeitsmarkt- und Berufsforschung (Institute for Employment Research). 
Goodwin, M. \& G. Maconachie. 2010. Redesigning the inspection blitz in the post Work Choices environment? In Work in Progress: Crises, Choices and Continuity: Proceedings of the 24th Conference, Association of Industrial Relations Academics of Australia and New Zealand, eds. A. Barnes, N. Balnave \& G. Lafferty. Sydney: AIRAANZ.

Hall, P. 1995. Remuneration and Equal Pay. In presentation by Senior Adviser to Sex Discrimination Commissioner to IIR conference on Equal Employment Opportunity. Sydney.

Healy, J., M. Kidd \& S. Richardson. 2007. Gender pay differentials in the low-paid labour market. Australian Fair Pay Commission.

Horrell, S., J. Rubery \& B.J. Burchell. 1989. Gender and Skill. Work, Employment and Society, vol. 4, 189-216.

International Labour Organisation. 2006. Statistics of Trade Union Membership. Geneva: ILO Bureau of Statistics.

Jackson, A. \& G. Schellenberg. 1999. Unions, Collective Bargaining and Labour Market Outcomes for Canadian Working Women: Past Gains and Future Challenges. In Research Report 11. Canadian Labour Congress.

Kanter, R. 1977. Men and Women of the Corporation. New York, Basic Books.

Kee, H.J. 2006. Glass Ceiling or Sticky Floor? Exploring the Australian Gender Pay Gap. Economic Record, vol. 82, no. 259, 408-427.

Kulich, C., G. Trojanowski, M.K. Ryan, S.A. Haslam \& L. Renneboog. 2011. Who gets the carrot and who gets the stick? Evidence of gender disparities in executive remuneration. Strategic Management Journal, vol. 32, 301-321.

Macarthy, P.G. 1975. Justice Higgins and the Harvester Judgement. In Social Policy in Australia: Some Perspectives 1901-1975, ed. J. Roe. Sydney, Cassell.

Mandel, H. \& M. Shalev. 2009. How Welfare States Shape the Gender Pay Gap: A Theoretical and Comparative Analysis. Social Forces, vol. 87, no. 4, 1873-1912.

Murray, G. 2006. Capitalist networks and social power in Australia and New Zealand. Aldershot, Ashgate.

Murray, G. \& D. Peetz. 2010. Women of the Coal Rushes. Sydney, University of NSW Press.

Niederle, M. \& L. Vesterlund. 2005. Do Women Shy Away from Competition? Do Men Compete too Much? In NBER working paper No. 11474. Cambridge, MA: National Bureau of Economic Research.

Nightingale, M. 1991. Facing the Challenge: Women in Victorian Unions. Melbourne: Victorian Trades Hall Council.

Norris, K., R. Kelly \& M. Giles. 2005. Economics of Australian Labour Markets. Sydney, Pearson Education.

Parker, J. \& J. Douglas. 2010. Can Women's Structures Help New Zealand and UK Trade Unions' Revival? Journal of Industrial Relations, vol. 52(4) 439-458.

Peetz, D. 2007. Collateral damage: women and the WorkChoices battlefield. Hecate, vol. 33, no. 1, 61-80.

Peetz, D. \& A. Preston. 2009. Individual contracting, collective bargaining and wages in Australia. Industrial Relations Journal, vol. 40, no. 5, 444-461.

Pfeffer, J. \& J. Ross. 1990. Gender-Based Wage Differences: The Effects of Organizational Context. Work and Occupations, vol. 17, 55-78.

Pocock, B. 1992. Women Count: Women in South Australian Trade Unions. Adelaide: Centre for Labour Studies, University of Adelaide.

---. 1995. Gender and Activism in Australian Unions. Journal of Industrial Relations, vol. 37 , no. 3, 377-400. 
Power, M. 1975. Woman's work is never done-by men: a socio-economic model of sex typing in occupations. Journal of Industrial Relations, vol. 17, no. 3.

Preston, A.C. 2000. Female earnings in Australia: an analysis of 1991 Census data. Australian Bulletin of Labour, vol. 26, no. 1, 38-58.

Reid, L. \& B. Rubin. 2003. Integrating economic dualism and labor market segmentation: the effects of race, gender and structural location on earnings, 1974-2000. Sociological Quarterly, vol. 44, no. 3, 405-432.

Rubery, J. 1995. Performance-related pay and the prospects for gender pay equity. Journal of Management Studies, vol. 32, no. 5, 637-645.

---. 2005. The shape of work and working time in the service sector. A segmentation approach. In Working in the Service Sector. A tale from different worlds, eds. G. Bosch \& S. Lehndorff. London, Routledge.

Shu, X. 2004. Education and Gender Egalitarianism: The Case of China. Sociology of Education, vol. 77, 311-336.

Smith, M. 2012. Social regulation of the gender pay gap in the EU. European Journal of Industrial Relations, vol. 18, no. 4, 365-380.

Storer, D. \& K. Hargreaves. 1976. Migrant Women in Industry. In Social Policy and Problems of the Workforce, Vol 1, , ed. S. Staats, 39-104. Melbourne, Social Welfare Unit, Australian Council of Trade Unions.

Tharenou, P. 2013. The Work of Feminists is Not Yet Done: The Gender Pay Gap-a Stubborn Anachronism. Sex Roles, vol. 68, no. 3-4, 198-206.

United Nations. 2005. Human Development Report 2004: Statistics. New York: UN.

Watson, I. 2009. The gender wage gap within the managerial workforce: an investigation using Australian panel data. In 2009 HILDA Survey Research Conference. University of Melbourne, Melbourne.

Whitehouse, G. 1990. Unequal Pay: A Comparative Study of Australia, Canada, Sweden and the UK. Labour and Industry, vol. 3, no. 2\&3, 354-71.

---. 1992. Legislation and Labour Market Gender Inequality: An Analysis of OECD CountriesL. Work Employment Society, vol. 6, no. 1, 65-86.

Whitehouse, G., D. Zetlin \& J. Earnshaw. 2001. Prosecuting equal pay: Evolving strategies in Britain and Australia. Gender, Work and Organisation, vol. 8, no. 4, 365-386.

Wooden, M. 1999. Gender Pay Equity and Comparable Worth in Australia: A Reassessment. Australian Economic Review, vol. 32, no. 2, 157-71.

Yu, K.-H. \& F. Levy. 2010. Offshoring Professional Services: Institutions and Professional Control. British Journal of Industrial Relations, vol. 458, no. 4, 758-783. 